\title{
Pendayagunaan Zakat Mal dalam Mengentaskan Kemiskinan (Study kasus Mustahiq Kelurahan Batua Kecamatan Manggala Kota Makassar)
}

\author{
Syarifuddin \\ Prodi Ekonomi Islam Fakultas Ekonomi dan Bisnis Islam UIN Alauddin Makassar \\ Jalan Sultan Alauddin, Samata Gowa \\ Email: syarifuddin7890@gmail.com
}

\begin{abstract}
This study aims to determine the use of zakat mal (productive and commercial) influence on poverty alleviation in Kelurahan Batua, Manggala District, Makassar City.

The research method used is descriptive quantitative research methods with econometric and Syar'i approaches. The sample used in this study were 100 respondents and this data was analyzed using chi-square test analysis and crostab analysis.

The results of the chi-square test results show that 0,000 is greater than the significance level of $a=0.05$, this shows that there is an effect of productive and commercial zakat utilization on poverty alleviation. The value of $\mathrm{P}$ (Risk) is $13.167 \%$, this means that mustahiq which utilizes its zakat on target is likely to increase its welfare by $13.167 \%$. Suggestions for BAZNAS of South Sulawesi Province should focus the program on one area that is favored to alleviate poverty through the empowerment of the community's economy so that the visible results of the utilization of zakat funds are visible.
\end{abstract}

Keywords: Utilization, Zakat Mal, Proverty

\begin{abstract}
Abstrak
Penelitian ini bertujuan untuk mengetahui pendayagunaan zakat mal (produktif dan komsutif) berpengaruh terhadap pengentasan kemiskinan di Kelurahan Batua Kecamatan Manggala Kota Makassar.

Metode penelitian yang digunakan adalah metode penelitian kuantitatif deskriptif dengan pendekatan ekonometrik dan Syar'i. Sampel yang digunakan dalam penelitian ini sebanyak 100 responden dan data ini dianalisis dengan menggunakan analisis uji chisquare dan analisis crostab.

Hasil penelitian dari Hasil uji chisquare menunjukan 0,000 lebih besar bila dibandingkan taraf signifikasi $a=0,05$ hal ini menunjukan bahwa ada pengaruh pendayagunaan zakat maal produktif dan komsumtif terhadap pengentasan kemiskinan. Nilai P (Risk) $13,167 \%$ hal ini berarti bahwa mustahiq yang mendayagunakan zakatnya secara tepat sasaran berpeluang untuk meningkatkan kesejahteraannnya sebesar 13,167\%. Saran bagi BAZNAS Prov. Sulsel hendaknya memfokuskan program pada satu bidang yang diunggulkan untuk mengentaskan kemiskinan melalui pemberdayaan ekonomi masyarakat agar terlihat hasil nyata dari pendayagunaan dana zakat tersebut.
\end{abstract}

Kata Kunci: Pendayagunaan, Zakat Mal, Kemiskinan.

\section{PENDAHULUAN}

Kemiskinan pada hakekatnya merupakan persoalan klasik yang telah ada sejak umat manusia ada. kemiskinan merupakan persoalan kompleks, dan tampaknya akan terus menjadi persoalan aktual dari masa ke masa, kemiskinan merupakan salah satu masalah yang selalu dihadapi oleh manusia. Masalah kemiskinan itu sama tuanya dengan usia kemanusian itu sendiri dan implikasinya permasalahannya dapat melibatkan keseluruhan aspek kehidupan manusia. (Suparlan, 1984)

Kemiskinan adalah keadaan penghidupan dimana orang tidak dapat memenuhi kebutuhan 
hidup dasar. (Sajogyo, 1983) Kemiskinan adalah realita sosial yang ditemui pada mayoritas penduduk Indonesia. Berdasarkan data Badan Pusat Statistik (BPS, 2012) jumlah penduduk miskin di Indonesia pada Maret 2012 mencapai 29,13 juta orang (11,96 persen), berkurang 0,89 juta orang $(0,53$ persen) dibandingkan dengan penduduk miskin pada Maret 2011 yang sebesar 30,02 juta orang (12,49 persen). (BPS, 2012) Sebenarnya kemiskinan akan dapat diminimalisir apabila ada distribusi pendapatan dan kekayaan yang merata. Persoalan yang nampak saat ini adalah sangat jelas terlihat adanya kesenjangan, baik kesenjangan sosial maupun ekonomi antara orang kaya dan miskin.

Salah satu cara menanggulangi masalah kemiskinan adalah dukungan orang yang mampu untuk mengeluarkan harta kekayaan mereka berupa dana zakat kepada mereka yang kekurangan. Zakat merupakan salah satu dari lima nilai instrumental yang strategis dan sangat berpengaruh pada tingkah laku ekonomi manusia dan masyarakat serta pembangunan ekonomi umumnya. Tujuan zakat tidak sekedar menyantuni orang miskin secara komsumtif, tetapi mempunyai tujuan lebih permanen yaitu mengentaskan kemiskinan. (Qadir, 2001) Menurut Yusuf Qardlawi, salah seorang ulama dan penulis yang sangat produktif, salah satu upaya mendasar dam fundamental untuk mengentaskan atau memperkecil masalah kemiskinan adalah dengan cara mengoptimalkan masalah Zakat. Hal itu dikarenakan zakat adalah sumber dana yang tidak akan pernah kering dan habis. dengan kata lain selama umat Islam memiliki kesadaran untuk berzakat dan selama dana zakat tersebut mampu dikelola dengan baik, maka dana zakat akan selalu selalu ada serta bermanfaat untuk kepentingan dan kesejahteraan masyarakat. (Kurniawati,2004)

Pendayagunaan zakat produktif sesungguhnya mempunyai perencanaan dan pelaksanaan yang cermat seperti mengkaji penyebab kemiskinan, ketidakadaan modal kerja, dan kekurangan lapangan kerja, dengan adanya masalah tersebut maka perlu adanya perencanaan yang dapat mengembangkan zakat bersifat produktif tersebut.

Zakat di Kota Makassar sebenarnya berpotensi dapat membantu keadaan masyarakatnya yang masih jauh dari taraf hidup mengingat penduduk kota makassar $90 \%$ beragama Islam, namun hal yang mengherankan tingkat kemiskinan di Kota Makassar meningkat dari tahun ketahun, sehingga muncul sebuah pertanyaan apakah pendistribusian zakat telah mencapai sasarannya, olehnya penulis tertarik melakukan penelitian Pendayagunaan zakat mal dalam mengentaskan kemiskinan (Study kasus Mustahiq kelurahan Batua kecamatan Manggala kota Makassar)

\section{Pendayagunaan Dana Zakat Mal dalam Pengentasan kemiskinan}

Pendayagunaan dana zakat, di dalam alQur'an surah At-Thaubah ayat 60 sebenarnya sudah sudah jelas diperuntukkan, yaitu untuk Ashnaf Tsamawiyyah (8 asnaf) atau yang biasa kita kenal dengan Mustahiq Zakat. Dalam UU No.38 tahun 1999 disebutkan bahwa hasil pengumpulan zakat didayagunakan untuk mustahiq sesuai dengan ketentuan agama dengan memperhatikan skala prioritas kebutuhan mustahiq dan bahkan dana zakat dapat dipergunakan untuk usaha yang bersifat produktif. (Mursyid, 2006)

Kemudian penyaluran dana zakat mal secara produktif dapat dilakukan melalui : Pemberian modal kerja dam pendampingan (dapat menggunakan Lembaga keuangan syariah atau lembaga keuangan Mikro Syariah), Penjaminan dana bagi mustadh'afiin apabila usahanya bermasalah (gharimin), Pendirian sector produksi/pabrik dan dikerjakan oleh mustadh'afin dan Usaha-usaha produktif lainnya.

Disamping dana zakat mal dapat dipergunakan kepada usaha-usaha yang bersifat produktif, dana zakat mal juga dapat dipergunakan dalam bentuk pemerian secara komsumtif, yaitu pemberian dana zakat untuk kenikmatan sesaat.(M. Syafe, 2009)

\section{Zakat Sebagai Instrumen Pengentasan Kemiskinan}

Zakatmerupakan instrument pengentasan kemiskinan yang efektif, ramah pasar, dan lestari. Zakat sebagai instrument pengentasan kemiskinan memiliki banyak keunggulan dibandingkan instrument fiskal konvensional. 
Pertama, penggunaan dana zakat sudah ditentukan secara jelas dalam syariat (QS at-Taubah (9): 60), yaitu zakat hanya diperuntukkan bagi delapan golongan (ashnaf) :orang-orang fakir miskin, amil zakat, muallaf, memerdekakan budak, orang-orang yang berhutang, fi sabilillah, dan ibnu sabil. Jumhur fuqaha sepakat bahwa selain 8 golongan diatas, tidak boleh menerima zakat. Tidak ada satu pihak pun yang berhak mengganti atau mengubah ketentuan ini. Karateristik ini membuat zakat secara inheren bersifat pro-poor. Tak ada satupun instrument fiskal konvensional yang memiliki karateristik unik seperti ini. Karena itu, zakat akan lebih efektif mengentaskan kemiskinan karena alokasi dana yang sudah pasti dan diyakini akan lebih tepat sasaran .

Kedua, Zakat sebagai tarif yang rendah dan tetap serta tidak pernah berubah-ubah karena sudah diatur dalam syariat. Misalnya, zakat perdagangan dalam arti luas, tarifnya hanya $2,5 \%$. Ketentuan tarif zakat ini tidak boleh diganti atau diubah oleh siapaun. Karena itu, penerapan zakat tidak akan mengganggu insentif investasi dan akan menciptakan tranparansi kebijakan public serta memberikan kepastian usaha.

Ketiga, zakat memiliki tarif berbeda untuk jenis harta yang berbeda, dan memberikan keringanan bagi usaha memiliki tingkat kesulitan produksi lebih tinggi. Misalnya, zakat untuk produk pertanian yang dihasilkan dari lahan irigasi tarifnya adalah 5\%. Sementara itu, jika dihasilkan dari lahan tadah hujan tarifnya $10 \%$. Karateristik ini membuat zakat bersifat market friendly, sehingga tidak akan mengganggu iklim usaha.

Keempat, zakat dikenakan pada basis yang luas dan meliputi berbagai aktifitas perekonomian. Zakat dipungut dari produk pertanian, hewan peliharaan, simpanan emas dan perak, aktiftas perniagaan komersial, dan barang-barang tambang yang diambil dari perut bumi. Fiqih kontemporer memandang bahwa zakat juga diambil dari seluruh pendapatan yang dihasilkan dari aset atau keahlian pekerja. Artinya, potensi zakat itu sangat besar. Hal ini menjadi modal besar yang penting bagi pembiayaan program-program pengentasan kemiskinan.
Kelima, Zakat adalah "pajak spiritual" yang wajib dibayar oleh setiap muslim terkena kewajiban berzakat dala kondisi apapun. Karena itu, penerimaan zakat cenderung stabil dan berkesinambungan. Hal ini akan menjamin keberlangsungan program-program pengentasan kemiskinan dalam jangka waktu yang cukup panjang.

\section{Pengaruh Zakat Terhadap Kemiskinan}

Jika dilihat Indonesia merupakan negara yang memiliki jumlah umat muslim terbesar di dunia harus memiliki peran aktif dalam perwujudan kesejahteraan masyarakat dengan pengoptimalan potensi zakat. Potensi ini tentu saja di anggap jelas mampu mewujudkan pengentasan kemiskinan, tetapi melalui pengelolaan dan mekanisme yang tepat dan mempunyai hasil baik. Potensi Zakat yang bisa dikembangkan untuk mengentaskan kemiskinan adalah zakat yang memiliki sifat produktif.(Amaliah, 2012)

Zakat produktif adalah pemberian zakat yang dapat membuat para penerimanya menghasilkan sesuatu secara terus-menerus, dengan harta zakat yang telah diterimanya. Dengan kata lain zakat dimana harta atau dana zakat yang diberikan kepada para mustahiq tidak dihabiskan akan tetapi dikembangkan dan digunakan untuk membantu usaha mereka, sehingga dengan usaha tersebut mereka dapat memenuhi kebutuhan hidup secara terus menerus. (Amaliah, 2012)

Pendayagunaan zakat produktif melalui cara atau usaha dalam mendatangkan hasil dan manfaat yang lebih besar serta lebih baik. Pemanfaatan zakat harta sangat targantung pada pengelolaannya. Apabila pengelolaannya baik, pemanfaatannya akan dirasakan oleh masyarakat. Pemanfaatan zakat ini, biasanya berbeda dari satu daerah ke daerah lain. Dari penelitian lapangan yang dilakukan diketahui bahwa pada umumnya bahwa penggunaan zakat harta diantaranya untuk pemberdayaan ekonomi mayarakat seperti; dipergunakan untuk usaha pertanian, peternakan dan usaha kecil lainnya.

\section{METODE PENELITIAN}

Metode yang digunakan dalam penelitian ini adalah deskriptif kuantitatif. Metode ini 
bertujuan untuk memberikan gambaran yang cukup jelas atas masalah yang diteliti.

Penelitian ini dilakukan Kelurahan Batua raya Kecamatan Manggala Kota Makassar yang dinaungi oleh BAZ NAS Prov Sulsel sebagai objek penelitian

Dalam penelitian ini penulis menggunakan beberapa metode pendekatan, yaitu pendekatan Ekonometrik dan pendekatan Syar'i,

Populasi dalam penelitian ini adalah anggota kelompok orang yang menerima zakat (mustahik zakat) baik melalui produktif dan komsumtif terletak di Kelurahan Batua di Kecamatan Manggala Kota Makassar.

Sampel Teknik yang digunakan pada penelitian ini menggunakan Purposive sampling yaitu pengambilan sampel yang didasarkan pada suatu pertimbangan tertentu yang dibuat oleh peneliti, Adapun pertimbangan menggunakan sampel 100 responden, jumlah penerima zakat produkif hanya 50 mustahiq maka sehingga peneliti mengambil 50 penerima zakat komsumtif. Adapun kriteria yang menjadi responden adalah:

Kriteria Inklusi: Penduduk miskin yang berdomisili di Kelurahan Batua Kecamatan Manggala, penerima zakat 1 tahun terakhir, dan berada dan bersedia untuk menjadi responden pada saat ada dilokasi penelitian.

Kriteria Enklusi: Penduduk miskin yang tidak berdomisili di Kelurahan Batua Kecamatan Manggala, penerima zakat tapi tidak menerima zakat 1 tahun terakhir, tidak berada dan bersedia menjadi responden pada saat dilokasi penelitian.

\section{Metode Pengumpulan Data}

Untuk memperoleh informasi dan data sebagai bahan penulisan ini, maka pengumpulan data yang digunakan oleh penulis :

a. Penelitian kepustakaan (Library Research) Dalam pelaksanaan metode ini, penulis mengadakan data berbagai literatur yang berkaitan dengan masalah yang dibahas.

b. Penelitian Lapangan (Field Research) Yaitu penelitian yang dilakukan untuk memperoleh data yang dibutuhkan pada objek yang berkaitan dalam hal ini Mustahiq Kelurahan Batua Kecamatan Manggala Kota Makassar.

\section{Instrumen Penelitian}

Instrumen penelitian adalah alat bantu bagi peneliti dalam mengumpulkan data. Instrumen penelitian yang digunakan yaitu menggunakan Angket yang merupakan daftar pertanyaan yang diberikan kepada objek penelitian yang mau memberikan respon sesuai dengan permintaan pengguna. (Iqbal, 1999) Angket penelitian digunakan untuk mengumpulkan data penelitian yang berupa pertanyaan yang diberikan kepada responden mustahiq dengan skala likert. Menurut Kinnear sebagaimana yang dikutip oleh Muhammad skala likert adalah skala yang berhubungan dengan pertanyaan tentang sikap seseorang terhadap sesuatu, dengan ukuran sebagai berikut: Sangat Setuju menunjukan angka 5, Setuju menunjukan angka 4, Cukup Setuju menunjukan angka3, Tidak Setuju menunjukan angka 2 dan Sangat Tidak Setuju menunjukan angka 1.

Pada dasarnya angket penelitian terdiri atas dua bagian pokok, yaitu: Bagian pengantar, yang terdiri atas (a) penjelasan tujuan angket penelitian, dan (b) surat rekomendasi atau dukungan dari pihak berwenang dan Bagian isi, yang terdiri atas (a) identitas umum responden dan (b) pertanyaan-pertanyaan utama.

\section{Metode analisis data}

\section{Uji Prasyarat}

Uji prasyarat yang digunakan dalam penelitian ini adalah untuk melakukan pengujian terhadap instrumen penelitian (kuisioner) yang meliputi uji realibilitas dan validitas. Validitas menunjukkan kinerja angket dalam mengukur apa yang diukur, sedangkan realibitas menunjukkan bahwa angket tersebut konsisten apabilah digunakan untuk mengukur gejala yang sama, tujuan pengujian validitas dan realibitas angket adalah untuk meyakinkan bahwa angket ayng disusun benar-benar baik dalam mengukur gejala dan menghasilkan data yang valid. (Sugiyono,2010)

Dalam penelitian ini, uji validitas dilakukan dengan membandingkan korelasi antara skor dari masing-masing item pertanyaan dengan skor totalnya. Teknik yang digunakan untuk 
melakukan perhitungan tersebut adalah korelasi produk moment person. Formula korelasi produk moment person yang sering digunakan oleh para peneliti dalam melakukan perhitungan tersebut, adalah seperti dibawah ini :

$\mathrm{r}_{\mathrm{xy}}=\sqrt{\frac{N \sum X Y-\left(\sum X\right)\left(\sum Y\right)}{\left[N \sum X^{2}-\left(\sum X\right)^{2}\right]\left[N \sum Y^{2}-\left(\sum Y\right)^{2}\right.}}$

Keterangan :

$r_{x y} \quad=$ Koefisien Korelasi

$X^{\text {xy }} \quad=$ Skor Butir

$\mathrm{Y} \quad=$ Skor total yang Diperoleh

$\mathrm{N} \quad=$ Jumlah Responden

$\sum X^{2}=$ Jumlah Kuadrat Nilai $X$

$\sum Y^{2}=$ Jumlah Kuadrat Nilai $Y$

Namun untuk lebih memudahkan dalam melakukan perhitungan korelasi tersebut, peneliti tidak melakukannya secara manual dengan menggunakan rumus di atas, akan tetapi menggunakan program SPSS dimana rumus tersebut di atas sudah terprogram di dalamnya sehingga peneliti dapat melakukan perhitungan dengan mudah, cepat dan tepat.

Sedangkan untuk instrumen angket dapat dikatakan reliabel apabila memberikan hasil yang konsisten bila menggunakan pendekatan analisis varian. Teknik uji realibitas yang diguanakan dalam penelitian ini, adalah Alpha Cronbach. Rumusnya yang sering dugunakan adalah seperti di bawah ini :

$$
a=\left[\frac{k}{k-1}\right]\left[1-\frac{\sum \pi_{b}^{2}}{\pi_{b}^{2}}\right]
$$

Keterangan :

$a \quad=$ Realibitas Instrumen

$\mathrm{k}=$ Banyaknya butir pertanyaan

$\sum \pi_{b}^{2}=$ Jumlah Varian Butir

$\pi_{b}^{2} \quad=$ Varian Total

Atau bisa juga menggunakan bantuan dari program SPSS di mana rumus tersebut sudah terprogram di dalamnya, sehingga hanya tinggal memasukkan data, kemudian diproses dan melihat nilai Cronbach's Alpha nya pada Reliability Statistics. Untuk menyatakan nilainya reliabel atau tidak, maka nilainya tersebut dikonsultasikan dengan interpretasi tingkat keandalan koefisien korelasi sebagai berikut :

1. Nilai : 0,000 - 0,190 = Sangat Rendah

2. Nilai : $0,200-0,399=$ Rendah

3. Nilai : $0,400-0,599=$ Sedang

4. Nilai : $0,600-0,799=$ Tinggi

5. Nilai : 0,800 - 0,100 = Sangat Tinggi.

\section{Analisis Deskriptif}

Dalam melakukan analisis terhadap hasil penelitian dilakukan analisis Analisis crosstab merupakan suatu metode analisis berbentuk tabel, dimana menampilkan tabulasi silang atau tabel kontingensi yang digunakan untuk mengidentifikasi dan mengetahui apakah ada korelasi atau hubungan antara satu variabel dengan variabel yang lain. Singkatnya, analisis crosstab merupakan metode untuk mentabulasikan beberapa variabel yang berbeda ke dalam suatu matriks. Tabel yang dianalisis di sini adalah hubungan antara variabel dalam baris dengan variabel dalam kolom.

Crosstabs (Tabulasi Silang) merupakan metode untuk mentabulasikan beberapa variabel yang berbeda ke dalam suatu matriks. Hasil tabulasi silang disajikan ke dalam suatu tabel dengan variabel yang tersusun sebagai kolom dan baris. Crosstabs ini mudah dipahami karena menyilangkan dua variabel dalam satu tabel.

\section{Uji Hipotesis}

Pengujian hipotesis dalam penelitian ini dalam rangka membuktikan adanya hubungan antara jenis zakat dengan pengentasan kemiskinan, data yang digunakan menggunakan data kategorik, untu data jenis kategorik analis yang tepat adalah menggunakan analisis Chi-Square disebut juga dengan Kai Kuadrat. Chi Square adalah salah satu jenis uji komparatif non parametris yang dilakukan pada dua variabel, di mana skala data kedua variabel adalah kategorikal. (Apabila dari 2 variabel, ada 1 variabel dengan skala nominal maka dilakukan uji chi square dengan merujuk bahwa harus digunakan uji pada derajat yang terendah. 


$$
x^{2}=\left[\frac{\Sigma\left(f_{0}-f_{e}\right)^{2}}{f_{e}}\right]
$$

Keterangan :

$X^{2}=$ Nilai chi-kuadrat

$\mathrm{f}_{\mathrm{e}}=$ Frekuensi yang diharapkan

$\mathrm{f}_{0}^{\mathrm{e}}=$ Frekuensi yang diperoleh/diamati. (Mason,1999).

\section{HASIL DAN PEMBAHASAN}

\section{Hasil}

Penelitian ini dilakukan Kelurahan Batua merupakan salah satu Kecamatan Manggala Terletak di sekitaran Kota Makassar, dan Kelurahan Batua Kecamatan Manggala yang dapat dicapai dengan kendaraan umum, Kemudian Kelurahan Batua Kec. Manggala : Terdiri dari 11 RW. Adapun jumlah penduduk Kelurahan Batua Kec. Manggala pada tahun 2016 adalah Mencapai 21.853 penduduk. Berdasarkan jenis kelamin laki-laki berjumlah 11.053 penduduk kemudian perempuan berjumlah 10.800 penduduk jadi jumlah penduduk di Kelurahan Batua sebanyak 21.853 penduduk.

Berdasarkan hasil penelitian bahwa bentuk pendayagunaan zakat mal di Kelurahan Batua dibagi menjadi dua jenis, yakni dengan menerapkan zakat produktif dan zakat komsumtif.

\section{Zakat Produktif}

Zakat produktif yaitu pemberian zakat kepada para Mustahiq dengan maksud agar pemberian tersebut dapat dimanfaatkan dalam waktu berkepanjangan dengan cara semisal ; dijadikan modal usaha agar keuntungan yang diperoleh dapat diputar untuk menjadi modal dihari-hari berikutnya. Dan cara inilah yang lebih diprioritaskan bagi pengelola zakat khususnya BAZNAS Prov. Sul-Sel karena dapat memberikan manfaat langsung dalam meningkatkan taraf kehidupan Mustahiq.

\section{Zakat komsumtif}

Zakat komsumtif yaitu pemberian zakat kepada Mustahiq yang bersifat komsumtif atau langsung dihabiskan pada saat digunakannya.
Tabel 1. Pendayagunaan Zakat Mal (Produktif dan Komsumtif) dikelurahan Batua Kecamatan Manggala Kota Makassar, Pada tahun 2016.

\begin{tabular}{ccc}
\hline Jenis Zakat & $\begin{array}{c}\text { Jumlah } \\
\text { Mustahiq }\end{array}$ & Persentase (\%) \\
\hline Produktif & 50 & $1.68 \%$ \\
Komsumtif & 2.944 & $98.32 \%$ \\
\hline Jumlah & 2.994 & $100 \%$ \\
\hline
\end{tabular}

Sumber data : BAZNAS Prov. Sul-Sel dan KUA Kec. Manggala Kel. Batua

Berdasarkan pada tabel 1. diatas bahwa yan paling banyak menerima zakat mal adalah penerima zakat komsumtif berjumlah 2.944 mustahiq atau $98.32 \%$ dan penerima zakat produktif adalah berjumlah 50 mustahiq. Dengan demikian dapat disimpulkan bahwa jumlah Mustahiq Zakat Komsumtif mendominasi dibandingkan dengan jumlah Mustahiq Zakat Produktif.

Tabel 2. Pendayagunaan Zakat Maal Untuk Kegiatan Produktif Berdasarkan Dana Zakat Yang disalurkan di kelurahan Batua Kecamatan Manggala Kota Makassar, Pada tahun 2016.

\begin{tabular}{ccc}
\hline $\begin{array}{c}\text { Dana Zakat Yang } \\
\text { Disalurkan }\end{array}$ & Frekuensi & Persentase (\%) \\
\hline 1.000 .000 & 16 & $32 \%$ \\
500.000 & 34 & $68 \%$ \\
\hline Jumlah & 50 & $100 \%$ \\
\hline
\end{tabular}

Sumber dari kantor Baznas Prov. Sulsel

Berdasarkan pada tabel diatas bahwa yang paling banyak dana zakat yang disalurkan untuk kegiatan produktif adalah 500.000 sebanyak 34 orang atau 68\%. Dan 1.000 .000 sebanyak 16 orang atau $32 \%$.

Tabel 3. Pendayagunaan Zakat Maal Untuk Kegiatan Produktif Berdasarkan Keuntungan Pendapatan di kelurahan Batua Kecamatan Manggala Kota Makassar, Pada tahun 2016.

\begin{tabular}{ccc}
\hline $\begin{array}{c}\text { Keuntungan } \\
\text { Pendapatan }\end{array}$ & Frekuensi & Persentase (\%) \\
\hline $125.000-250.000$ & 12 & $24 \%$ \\
$300.000-500.000$ & 10 & $20 \%$ \\
$550.000-1.000 .00$ & 28 & $56 \%$ \\
\hline Jumlah & 50 & $100 \%$ \\
\hline
\end{tabular}

Sumber dari kantor Baznas Prov. Sulsel

Berdasarkan pada tabel diatas bahwa yang paling banyak keuntungan pendapatan 
adalah $550.000-1.000 .000$ sebanyak 28 orang atau 56\%. Dan 125.000-250.000 sebanyak 12 orang atau $24 \%$. Dan yang terakhir 300.000 500.000 sebanyak 10 orang atau $20 \%$.

Tabel 4. Pendayagunaan Zakat Mal Untuk Kegiatan Produktif Berdasarkan Jenis Usaha di kelularan Batua Kecamatan Manggala Kota Makassar, Pada tahun 2016.

\begin{tabular}{lcc}
\hline \multicolumn{1}{c}{ Jenis Usaha } & Frekuensi & Persentase (\%) \\
\hline Pedagang & 13 & $26 \%$ \\
Menjahit & 11 & $22 \%$ \\
Tampal ban & 5 & $10 \%$ \\
Jual Sticker & 3 & $6 \%$ \\
Jual kue-kue & 11 & $22 \%$ \\
Jual Es buah & 4 & $8 \%$ \\
Jual Cendol & 3 & $6 \%$ \\
\hline \multicolumn{1}{c}{ Jumlah } & 50 & $100 \%$ \\
\hline
\end{tabular}

Sumber data Baznas Prov. Sulsel.

Berdasarkan Pada tabel diatas bahwa yang paling banyak jenis usaha adalah pedagang kaki lima sebanyak 13 orang atau $26 \%$. Kemudian menjahit dan jual kue-kue masing-masing 11 orang atau $22 \%$.

Tabel 5. Deskripsi Penerima Zakat berdasarkaan Pendayagunaannya.

\begin{tabular}{ccc}
\hline Jenis Zakat & Frekueansi & Persentase (\%) \\
\hline Tepat Sasaran & 79 & $79 \%$ \\
Kurang Tepat Sasaran & 12 & $12 \%$ \\
\hline Jumlah & 100 & $100 \%$ \\
\hline
\end{tabular}

Sumber data : Kelurahan Batua Kec. Manggala

Berdasarkan Pada Tabel penerima zakat (Mustahiq) berdasarkan jenis zakat yang lebih banyak responden yang menerima Zakat Komsumtif sebanyak 59 (59\%).

Berdasarkan Pada tabel bahwa yang paling banyak tingkat kemiskinan adalah Miskin sekali berjumlah 54 atau 54\%. Dan miskin berjumlah 46 atau $46 \%$. Jadi yang paling didominasi adalah Miskin sekali daripada miskin.
Tabel 6. Deskripsi Tingkat Kemiskinan menurut zakat yang diterimah responden Di kelurahan Batua Kecamatan Manggala Kota Makassar.

\begin{tabular}{lcc}
\hline \multicolumn{1}{c}{ Jenis Zakat } & Frekueansi & Persentase (\%) \\
\hline Miskin Skali & 9 & $56 \%$ \\
Miskin & 79 & $44 \%$ \\
\hline \multicolumn{1}{c}{ Jumlah } & 100 & $100 \%$ \\
\hline
\end{tabular}

\section{Analisis Uji Chis-quare}

\section{Uji Hipotesis}

Hasil penelitian menunjukkan bahwa lebih banyak responden yang menggunakan zakatnya tepat sasaran yang terdapat pada kelompok miskin sebesar 79 orang (79\%).

Hasil uji chisquare menunjukan 0,000 lebih besar bila dibandingkan taraf signifikasi a $=0,05$ hal ini menunjukan bahwa ada pengaruh pendayagunaan zakat maal produktif dan komsumtif terhadap pengentasan kemiskinan. Nilai P (Risk) 13,167\% hal ini berarti bahwa mustahiq yang mendayagunakan zakatnya secara tepat sasaran berpeluang untuk meningkatkan kesejahteraannnya sebesar $13,167 \%$.

\section{Pembahasan}

Cara bentuk pendayagunaan zakat mal di Kelurahan Batua dibagi menjadi dua jenis, yakni dengan menerapkan zakat produktif dan zakat komsumtif. Zakat produktif yaitu pemberian zakat kepada para Mustahiq dengan maksud agar pemberian tersebut dapat dimanfaatkan dalam waktu berkepanjangan dengan cara semisal ; dijadikan modal usaha agar keuntungan yang diperoleh dapat diputar untuk menjadi modal dihari-hari berikutnya. Dan cara inilah yang lebih diprioritaskan bagi pengelola zakat khususnya BAZNAS Prov. Sul-Sel karena dapat memberikan manfaat langsung dalam meningkatkan taraf kehidupan Mustahiq. Sedangkan Zakat komsumtif yaitu

Tabel 7. Ringkasan hasil Uji Chi square

\begin{tabular}{|c|c|c|c|c|c|c|c|c|}
\hline \multirow{3}{*}{ Pendayagunaan } & \multicolumn{4}{|c|}{ Tingkat Kemiskinan } & \multirow{2}{*}{\multicolumn{2}{|c|}{ Total }} & \multirow{3}{*}{$\begin{array}{c}\text { Person } \\
\text { Chis-quare }\end{array}$} & \multirow{3}{*}{ P (Risk) } \\
\hline & \multicolumn{2}{|c|}{ Miskin } & \multicolumn{2}{|c|}{ Miskin sekali } & & & & \\
\hline & $\mathbf{N}$ & $\%$ & $\mathbf{N}$ & $\%$ & $\mathbf{N}$ & $\%$ & & \\
\hline Tepat Sasaran & 79 & $79 \%$ & 3 & $3 \%$ & 82 & $83 \%$ & \multirow{3}{*}{0,000} & \multirow{3}{*}{13,167} \\
\hline Kurang Tepat Sasaran & 12 & $12 \%$ & 6 & $67 \%$ & 18 & $59 \%$ & & \\
\hline Jumlah & 91 & $91 \%$ & 9 & $9 \%$ & 100 & $100 \%$ & & \\
\hline
\end{tabular}


pemberian zakat kepada Mustahiq yang bersifat komsumtif atau langsung dihabiskan pada saat digunakannya.

Hasil penelitian menunjukkan nilai 0,000 lebih besar bila dibandingkan taraf signifikasi a $=0,05$ hal ini menunjukan bahwa ada pengaruh pendayagunaan zakat mal produktif dan komsumtif terhadap pengentasan kemiskinan.

Menurut Amalia, Kasyful (2012) pengoptimalan potensi zakat. Potensi ini tentu saja di anggap mampu mewujudkan pengentasan kemiskinan, tetapi melalui pengelolaan dan mekanisme yang tepat dan mempunyai hasil baik. Potensi Zakat yang bisa dikembangkan untuk mengentaskan kemiskinan adalah zakat yang memiliki sifat produktif. ${ }^{1}$ Hasil penelitian menunjukan ada pengaruh antara zakat dan pengentasan kemiskinan, sehingga dapat di simpulkan bawa hasil penelitian ini mendukung teori tersebut. Meskipun demikian hasil penelitian masih lebih banyak mendistribusikan zakat dalam bentuk zakat konsumtif.

Berdasarkan Devialina Puspita (2008) tentang "Pengaruh Pendayagunaan Zakat Terhadap Keberdayaan Dan Pengentasan Kemiskinan Rumah Tangga (Kasus: Program Urban Masyarakat Mandiri, Kelurahan Bidaracina, Kecamatan Jatinegara, Jakarta Timur)“ menunjukkann bahwa Dana zakat melalui Program Urban Masyarakat Mandiri Bantuan MM belum berpengaruh nyata terhadap upaya pengentasan kemiskinan. Hal ini terlihat dari masih rendahnya pendapatan mitra yang berimplikasi kepada belum tercapainya mitra yang sejahtera. ${ }^{2}$ hasil penelitian ini sejalan dengan penelitian sebelumnya.

Tidak tercapainya sasaran dalam pengentasan kemiskinan disebakan oleh ada umumnya para responden mengeluhkan kondisi usaha yang semakin sulit, keadaan tersebut ternyata akar permasalannya adalah bukan terletak dari bantuan itu sendiri. Namun, ada faktor eksternal yaitu faktor kebijakan pemerintah yaitu dengan menaikkan harga

\footnotetext{
${ }^{1}$ Jurnal Ekonomi dan keuangan. Hal.72

${ }^{2}$ Devialina Puspita (2008) Pengaruh Pendayagunaan Zakat Terhadap Keberdayaan dan Pengentasan Kemiskinan Rumah Tangga (Kasus: Program Urban Masyarakat Mandiri, Kelurahan Bidaracina, Kecamatan Jatinegara, Jakarta Timur)
}

Bahan Bakar Minyak (BBM) yang berimplikasi terhadap kenaikan biaya hidup lainnya seperti kenaikan Sembilan Bahan Pokok (Sembako) yang merupakan bahan dasar jualan mereka, biaya transportasi (angkot, ojek, dll), sehingga dapat dikatakan bahwa pemberian bantuan modal usaha hanya dapat membuat mitra untuk memutar modalnya saja, belum sampai tahap menyejahterakan apalagi mengentaskan kemiskinan.

Soekarni et.al. (2008) Meneliti Potensi dan Peran Zakat Dalam Mengurangi Kemiskinan", Bahwa Hasil dari penelitian tersebut yang menyebutkan bahwa secara umum pengelolaan zakat yang telah dilakukan di lokasi penelitian belum mampu mengurangi jumlah orang miskin secara signifikan. Tingkat keberhasilan lembaga-lembaga pengelola zakat, terutama BAZIS DKI Jakarta, BAZDA Banjarnegara, BAZ Pekasiran dan LAZIS Baitul Makmur Kepakisan, baru sampai pada tingkat mengurangi beban hidup oranga miskin. Hasil dari penelitian ini juga tidak sejalan dengan penelitian sebelumnya.

Kenyatan ini disebabkan oleh program penyaluran zakat lebih banyak diarahkan untuk hal-hal yang bersifat konsumtif. Selain itu, nilai bantuan yang diberikan juga relatif kecil karena dana yang terkumpul masi terbatas, sedangkan jumlah orang yang perlu dibantu sangat banyak. Sementara pengelolaan zakat oleh Dompet Dhuafa Republika dan Pos Keadilan Peduli Umat telah memberikan kontribusi yang cukup berarti. Prestasi kedua LAZ ini dicapai dengan cara mengalokasikan zakat dalam porsi yang relatif besar kepada para mustahik dalam bentuk usaha-usaha produktif yang diikuti dengan pemberian bimbingan dan pendampingan.

Berdasarkan teori, penelitian sebelumnya dan hasil penelitian ini maka ditegaskan bahwa ada "Pengaruh Pendayagunaan Zakat Mal dalam mengentaskan kemiskinan (Study Kasus Mustahiq Kelurahan Batua Kec. Manggala Kota Makassar)."

\section{KESIMPULAN}

Dari hasil penelitian yang dilakukan terhadap pendayagunaan Zakat Mal dalam Mengentaskan kemiskinan sebagai berikut: 
Cara bentuk pendayagunaan zakat mal di Kelurahan Batua dibagi menjadi dua jenis, yakni dengan menerapkan zakat produktif dan zakat komsumtif. Zakat produktif yaitu pemberian zakat kepada para Mustahiq dengan maksud agar pemberian tersebut dapat dimanfaatkan dalam waktu berkepanjangan dengan cara semisal ; dijadikan modal usaha agar keuntungan yang diperoleh dapat diputar untuk menjadi modal dihari-hari berikutnya. Dan cara inilah yang lebih diprioritaskan bagi pengelola zakat khususnya BAZNAS Prov. Sul-Sel karena dapat memberikan manfaat langsung dalam meningkatkan taraf kehidupan Mustahiq. Sedangkan Zakat komsumtif yaitu pemberian zakat kepada Mustahiq yang bersifat komsumtif atau langsung dihabiskan pada saat digunakannya.

Hasil uji Chisquare menunjukkan nilai signifikasi sebesar 0.000 bila dibandingkan dengan a (0.05) menunjukan nilai sig < a hal ini Menunjukkan bahwa ada "Pengaruh Pendayagunaan Zakat Mal dalam pengentasan kemiskinan di Kelurahan Batua Kec. Manggala Kota Makassar." . Nilai P (Risk) 13,167\% hal ini berarti bahwa Mustahiq yang mendayagunakan zakatnya secara tepat sasaran berpeluang untuk meningkatkan kesejahteraannnya sebesar $13,167 \%$.

\section{DAFTAR PUSTAKA}

Amaliah, (2012), Jurnal Ekonomi dan keuangan. Arikunto, Suharsono. Prosedur Penelitian: Suatu Pendekatan Praktik.

Abdul Muhid. (2010). Analisis Statistik SPSS for Windows: Cara Praktis Melakukan Analisis Statistik. Surabaya: CV Duta Aksara.
Abdurahman Qadir, Zakat Dalam Dimensi Mahdah dan Sosial, Jakarta : Raja Grafindo Persada, 2001.

Abu Ahmadi, Narbuko, Cholid. Metodologi Penelitian. Jakarta: Bumi Aksara, 2007.

Badan Pusat Statistik. 2012. Profil Kemiskinan di Indonesia Maret 2012. Berita Resmi Statistik, No. 45/07/Th. XV, 2 Juli 2012.

Darmuin, Ilyas Supena. Manajemen Zakat, Semarang: Walisongo Press, 2009.

Devialina Puspita (2008) Pengaruh Pendayagunaan Zakat Terhadap Keberdayaan dan Pengentasan Kemiskinan Rumah Tangga (Kasus: Program Urban Masyarakat Mandiri, Kelurahan Bidaracina, Kecamatan Jatinegara, Jakarta Timur).

Douglas, Mason. Teknik Statistik Untuk Bisnis dan Ekonomi, Jakarta:Erlangga, 1999.

Hasan, M.Iqbal. Pokok-Pokok Materi Statistik, Cet. I; jakarta Aksara, 1999.

http://hasanismailr.blogspot.co.id/2009/06/ pengertian-pendayagunaan-zakat.html.

Kurniawati, Kedermawaan kaum muslimin, Jakarta : Piramedia, 2004.

M.syafe'I EI-Bantanie, Zakat, Infak, dan Sedekah, Bandung: Salamadani, 2009.

Mursyid, Mekanisme Pengumpulan Zakat Infak Shadaqah Menurut Hukum Syara' dan Undang-Undang, Samarinda Magistra Insania Press, 2006.

Sajogyo, Sosiologi Pedesaan, cet, I, Yogyakarta : Gajahmada University Press, 1983.

Suparlan, Parsudi. Kemiskinan di perkotaan, Jakarta : Yayasan Obor Indonesia,1984.

Sugiyono. Metode penelitian Pendidikan Bandung: Alfabeta, cv. 2010.

www.Analisis Crosstab.live and life.htm. 